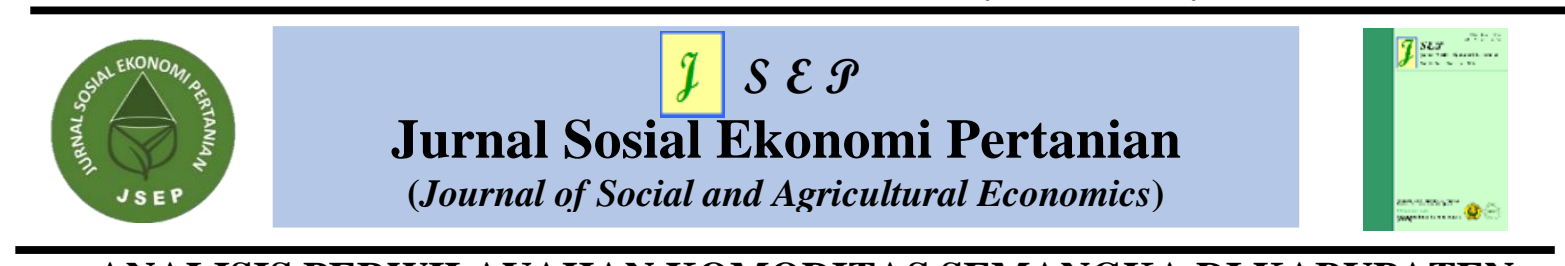

\title{
ANALISIS PERWILAYAHAN KOMODITAS SEMANGKA DI KABUPATEN
} BANYUWANGI

\section{REGIONAL ANALYSIS OF WATERMELON COMMODITIES IN BANYUWANGI REGENCY}

\author{
Yunita Mayangsari ${ }^{1}$, Aryo Fajar Sunartomo ${ }^{1 *}$ \\ ${ }^{1}$ Program Studi Agribisnis, Fakultas Pertanian, Universitas Jember \\ *Corresponding author's email: aryo.faperta@unej.ac.id
}

Submitted: 03/02/2021 Revised: 26/07/2021 Accepted: 31/07/2021

\begin{abstract}
Watermelon commodity has the highest productivity compared to other superior fruit commodities in Banyuwangi Regency. However, the land area and production of watermelon commodities are still quite volatile and their distribution is uneven. Therefore, a regional approach for watermelon commodities is needed in Banyuwangi Regency. This study aimed to determine the watermelon commodity base area, the characteristics of the watermelon commodity distribution, and the carrying capacity of the watermelon commodity on fruit horticultural crops in the Banyuwangi Regency. The determination of the research area was carried out intentionally in Banyuwangi Regency. The analytical methods used were Location Quotient (LQ) analysis, localization and specialization analysis, as well as Basic Service Ratio (BSR) and Regional Multiplier (RM) analysis. The results of the analysis show that the sub-district area was the basis for watermelon commodities in Banyuwangi Regency. The characteristics of the distribution of watermelon commodities in the Banyuwangi Regency were not localized. Watermelon farming activities are not concentrated in one sub-district but spread to several sub-districts in Banyuwangi Regency. The results of the analysis of the Basic Service Ratio (BSR) and Regional Multiplier (RM) of watermelon commodities produce more than one value. The existence of watermelon commodity farming activities can support fruit horticultural farming activities in Banyuwangi Regency.
\end{abstract}

Keywords: regional analysis, banyuwangi regency, watermelon

\begin{abstract}
ABSTRAK
Komoditas semangka memiliki produktivitas tertinggi dibandingkan dengan komoditas buah unggulan lainnya di Kabupaten Banyuwangi. Akan tetapi, luas lahan dan produksi komoditas semangka masih tergolong fluktuatif dan penyebarannya tidak merata. Oleh karena itu, diperlukan suatu pendekatan perwilayahan komoditas semangka di Kabupaten Banyuwangi.Penelitian ini bertujuan untuk mengetahui wilayah basis komoditas semangka, karakteristik penyebaran komoditas semangka dan daya dukung komoditas semangka terhadap tanaman hortikultura buah di Kabupaten Banyuwangi. Penentuan daerah penelitian dilakukan secara sengaja di Kabupaten Banyuwangi. Metode analisis yang digunakan adalah analisis Location Quotient (LQ), analisis lokalisasi dan spesialisasi, serta analisis Basic Service Ratio (BSR) dan Regional Multiplier (RM). Hasil analisis menunjukkan bahwa Wilayah kecamatan yang menjadi basis komoditas semangka di Kabupaten Banyuwangi. Karakteristik penyebaran komoditas semangka di Kabupaten Banyuwangi tidak terlokalisasi. Kegiatan usahatani komoditas semangka tidak terpusat pada satu wilayah kecamatan saja melainkan menyebar ke beberapa wilayah kecamatan di Kabupaten Banyuwangi. Hasil analisis Basic Service Ratio (BSR) dan Regional Multiplier (RM) komoditas semangka menghasilkan nilai lebih dari satu. Keberadaan kegiatan usahatani komoditas semangka mampu mendukung kegiatan usahatani tanaman hortikultura buah di Kabupaten Banyuwangi.
\end{abstract}

Kata kunci: analisis perwilayahan, kabupaten banyuwangi, semangka

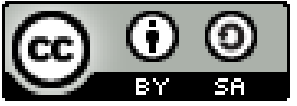

Copyright (C) 2021 by Author(s)

This work is licensed under a Creative Commons Attribution-ShareAlike 4.0 International

License. All writings published in this journal are personal views of the authors and do not represent the views of this journal and the author's affiliated institutions.

How to Cite: Mayangsari, Y., Sunartomo, A.F. (2021). Analisis Perwilayahan Komoditas Semangka Di Kabupaten Banyuwangi. JSEP: Jurnal Sosial Ekonomi Pertanian, 14(2): 180-200. 


\section{PENDAHULUAN}

Pembangunan ekonomi daerah merupakan suatu proses kerjasama antara pemerintah daerah dan masyarakatnya dalam mengelola sumberdaya yang dimiliki oleh daerah tersebut. Pembangunan ekonomi daerah harus sesuai dengan kondisi potensi daerah yang bersangkutan karena setiap daerah memiliki potensi sumberdaya spesifik lokasi yang berbeda. Potensi ekonomi daerah ialah kemampuan ekonomi daerah yang memungkinkan dan layak untuk dikembangkan sehingga dapat dijadikan sebagai sumber penghidupan masyarakat daerah setempat secara berkesinambungan (Tumangkeng, 2018).

Komoditas semangka merupakan komoditas hortikultura buah yang memiliki potensi pengembangan yang cukup cerah. (Daniel, 2016) menyatakan bahwa semangka mengandung zat-zat dan nutrisi yang baik untuk kesehatan dan kecantikan. Buah semangka hampir $99 \%$ bagiannya terdiri dari air, namun dalam pertumbuhannya tanaman semangka tidak membutuhkan banyak air sehingga sangat menguntungkan petani apabila ditanam di musim kemarau. Iklim kering dan panas, sinar matahari yang terpancar sepanjang hari dan air yang cukup merupakan kebutuhan utama dalam menanam semangka. Syarat tumbuh semangka yang sesuai dengan dengan kondisi wilayah di Indonesia menjadi alasan penanaman semangka menyebar luas di pelosok Indonesia.

Berdasarkan data (Dirjen_Hortikultura, 2017), terdapat tiga provinsi yang memiliki share produksi komoditas semangka tertinggi di Indonesia. Provinsi tersebut yaitu Jawa Timur, Sumatera Utara dan Jawa Tengah. Jawa Timur menempati peringkat pertama sebagai produsen semangka tertinggi di Indonesia. Jawa Timur memiliki luas lahan dan produksi terbesar di Pulau Jawa bahkan secara nasional tersebut tidak terlepas dari kontribusi wilayahnya seperti Kabupaten Banyuwangi yang menjadi salah satu sentra semangka di Jawa Timur. Kementerian_Pertanian (2017) menginformasikan bahwa Kabupaten Banyuwangi menempati peringkat pertama dengan rata-rata produksi sebesar 45.727 ton/tahun dan rata-rata share produksi sebesar 32,4552\%.

Disperta_Banyuwangi (2018) menyatakan bahwa komoditas semangka tergolong dalam komoditas hortikultura buah unggulan di Kabupaten Banyuwangi. Kabupaten Banyuwangi sendiri mempunyai dua puluh enam jenis komoditas hortikultura buah yaitu alpukat, belimbing, duku, durian, jambu air, jambu biji, jeruk besar, jeruk siam, mangga, manggis, markisa, nanas, nangka, papaya, pisang, rambutan, salak, sawo, sirsak, sukun, melinjo, petai, anggur, melon, semangka, dan buah naga. Diantara dua puluh enam komoditas buah tersebut terdapat sembilan jenis buah yang tergolong menjadi komoditas ungulan Kabupaten Banyuwangi yaitu buah semangka, melon, manggis, jeruk siam, durian, mangga, buah naga, rambutan, dan pisang. Komoditas semangka menjadi komoditas unggulan yang selama tahun 2014-2018 memiliki produktivitas yang fluktuatif namun rata-rata maupun jumlah nilai produktivitasnya tertinggi dibandingkan dengan komoditas unggulan lainnya di Kabupaten Banyuwangi.

Guna memetakan wilayah dengan komoditas unggulan tertentu diperlukan suatu klasterisasi wilayah. Hal ini bertjuan untuk menentukan posisi komoditas semangka di Banyuwangi. Selain itu, klasterisasi digunakan untuk acuan dalam perencanaan pembangunan wilayah Banyuwangi baik dalam jangka pendek maupun jangka panjang. Berdasarkan data tersebut menjadi penting untuk melakukan penelitian terkait klasterisasi komoditas semangka di Banyuwangi, karena adanya klasterisasi akan membantu pemerintah untuk melihat komoditas unggulan khususnya hortikultura di Banyuwangi.

Penelitian terkait analisis perwilayahan sudah banyak dilakukan yaitu penelitian (Bangun, 2020; Firdaus et al., 2009; Hendayana, 2003; Kartikaningdyah, 2012; Keratorop 
et al., 2016; Mulyono \& Munibah, 2016; Qomariyah et al., 2018; Supriyanto et al., 2017). Sedangkan penelitian terkait analisis perwilayahan komoditas semangka juga sudah pernah dilakukan oleh (Sihotang, 2019) di Sumatera Utara. Kebaruan penelitian ini adalah penelitian perwilayahan komoditas semangka di lakukan di Banyuwangi Jawa Timur dengan mendasarkan pada keunggulan luas lahan dan produksi, selain itu penelitian ini juga membahas mengenai daya dukung komoditas semangka terhadap pengembangan hortikultura di Banyuwangi.

Tujuan dari penelitian ini ialah untuk mengetahui: 1) Wilayah kecamatan yang menjadi basis komoditas semangka berdasarkan indikator luas lahan dan produksi di Kabupaten Banyuwangi. 2) Apakah karakteristik penyebaran komoditas semangka di Kabupaten Banyuwangi terlokalisasi dan terspesialisasi berdasarkan indikator luas lahan dan produksi. 3) Apakah sektor basis komoditas semangka di Kabupaten Banyuwangi mendukung atau tidak dalam pengembangan kegiatan usahatani tanaman hortikultura buah di Kabupaten Banyuwangi.

\section{METODE PENELITIAN}

Penentuan daerah penelitian menggunakan metode purposive method (disengaja) yaitu di Kabupaten Banyuwangi Provinsi Jawa Timur. Dasar pertimbangan pemilihan lokasi di Kabupaten Banyuwangi yaitu Kabupaten Banyuwangi merupakan salah satu kabupaten yang menjadi sentra produksi semangka di provinsi Jawa Timur, buah semangka menjadi komoditas dan sumber pendapatan utama petani Banyuwangi, semangka di Kabupaten Banyuwangi dipanen empat kali dalam setahun dan ditanam sepanjang tahun, serta keuntungan usahatani semangka di Banyuwangi yang sangat tinggi. Waktu penelitian dilaksanakan pada Bulan Februari 2020 sampai Desember 2020.

Penelitian ini merupakan penelitian kuantitatif dengan menggunakan metode analitik. Metode pengumpulan data yang digunakan dalam penelitian ini yaitu metode observasi dan metode dokumentasi. Data yang diperoleh dari metode observasi ini berupa data primer yautu berupa hasil dari mengamati kondisi lahan pertanian dan kegiatan petani semangka dalam melakukan budidaya komoditas semangka di Kabupaten Banyuwangi. Data sekunder dalam penelitian ini diperoleh dari Badan Pusat Statistik (BPS), Dinas Pertanian, Kehutanan dan Perkebunan Kabupaten Banyuwangi, serta artikel serta literatur-literatur lainnya yang relevan dengan tujuan penelitian dalam bentuk dokumen-dokumen dan laporan-laporan yang terkait penelitian.

Metode analisis data yang digunakan untuk mengetahui wilayah kecamatan basis komoditas semangka di Kabupaten Banyuwangi yaitu menggunakan analisis Location Quotient (LQ) dengan rumus sebagai berikut (Warpani, 1980):

Keterangan:

$$
\mathrm{LQi}=\frac{\mathrm{S}_{\mathrm{i}} / \mathrm{N}_{\mathrm{i}}}{\mathrm{S} / \mathrm{N}}
$$

LQi = Besarnya nilai LQ komoditas semangka di kecamatan i pada Kabupaten Banyuwangi

$\mathrm{Si}=$ Produksi dan luas lahan komoditas semangka di kecamatan

$\mathrm{S}=$ Produksi dan luas lahan komoditas holtikultura buah di kecamatan

$\mathrm{Ni}=$ Produksi dan luas lahan komoditas semangka di Kabupaten Banyuwangi

$\mathrm{N}$ = Produksi dan luas lahan komoditas holtikultura buah di Kabupaten Banyuwangi

Kriteria pengambilan keputusan:

a.Jika nilai LQi > 1, maka kecamatan i merupakan wilayah basis komoditas semangka di Kabupaten Banyuwangi. 
b. Jika nilai LQi $<1$, maka kecamatan i merupakan wilayah yang menjadi non basis komoditas semangka di Kabupaten Banyuwangi.

c.Jika nilai $\mathrm{LQi}=1$, maka kecamatan i mengalami keseimbangan atau daerah yang bersangkutan telah mencukupi dalam kegiatan tertentu.

Karakteristik penyebaran komoditas semangka di Kabupaten Banyuwangi dapat diketahui dengan menggunakan analisis nilai koefisien lokalisasi dan koefisien spesialisasi. Analisis koefisien lokalisasi digunakan untuk mengetahui apakah usaha kegiatan komoditas semangka tersebar ke beberapa wilayah di Kabupaten Banyuwangi atau hanya terpusat di wilayah tertentu. Menurut (Warpani, 1980), berikut merupakan rumus yang digunakan dalam perhitungan analisis lokalisasi:

Keterangan:

$$
\alpha \mathrm{i}=[\mathrm{Si} / \mathrm{Ni}]-[\mathrm{S} / \mathrm{N}]
$$

$\alpha \mathrm{i}=$ Koefisien lokalisasi yang bertanda positif dengan nilai $0 \leq \alpha \leq 1$

$\mathrm{Si}=$ Produksi dan luas lahan komoditas semangka di kecamatan

$\mathrm{S}=$ Produksi dan luas lahan komoditas holtikultura buah di kecamatan

$\mathrm{Ni}=$ Produksi dan luas lahan komoditas semangka di Kabupaten Banyuwangi

$\mathrm{N}$ = Produksi dan luas lahan komoditas holtikultura buah di Kabupaten Banyuwangi

Kriteria pengambilan keputusan:

a. Jika $\alpha \geq 1$, maka kegiatan usaha komoditas semangka terkonsentrasi pada suatu wilayah kecamatan di Kabupaten Banyuwangi.

b. Jika $\alpha<1$, maka kegiatan usaha komoditas semangka menyebar di beberapa wilayah kecamatan di Kabupaten Banyuwangi.

Analisis spesialisasi digunakan untuk mengetahui apakah wilayah kecamatan di Kabupaten Banyuwangi mengkhususkan atau tidak wilayah kecamatannya pada jenis kegiatan usaha komoditas semangka. Menurut (Warpani, 1980), berikut merupakan rumus yang digunakan dalam perhitungan analisis spesialisasi:

Keterangan:

$$
\beta \mathrm{i}=[\mathrm{Si} / \mathrm{S}]-[\mathrm{Ni} / \mathrm{N}]
$$

$\beta \mathbf{i}=$ Koefisien spesialisasi, yang bertanda positif dengan nilai $0 \leq \beta \leq 1$

$\mathrm{Si}=$ Produksi dan luas lahan komoditas semangka di kecamatan

$\mathrm{S}=$ Produksi dan luas lahan komoditas holtikultura buah di kecamatan

$\mathrm{Ni}=$ Produksi dan luas lahan komoditas semangka di Kabupaten Banyuwangi

$\mathrm{N}$ = Produksi dan luas lahan komoditas holtikultura buah di Kabupaten Banyuwangi

Kriteria pengambilan keputusan:

a. Jika nilai $\beta \geq 1$, maka suatu wilayah kecamatan di Kabupaten Banyuwangi terspesialisasi pada satu jenis kegiatan usaha semangka.

b. Jika nilai $\beta<1$, maka suatu wilayah kecamatan di Kabupaten Banyuwangi tidak terspesialisasi pada satu jenis kegiatan usaha semangka.

Analisis Basic Service Ratio (BSR) dan Analisis Regional Multiplier (RM) digunakan untuk mengetahui apakah kegiatan usaha komoditas semangka dapat mendukung kegiatan tanaman hortikultura buah di Kabupaten Banyuwangi. Analisis Basic Service Ratio (BSR) digunakan untuk mengetahui apakah komoditas semangka memiliki dampak pengganda pada kegiatan subsektor hortikultura buah yang lain. Berikut merupakan rumus yang digunakan dalam menghitung Basic Service Ratio (BSR) komoditas semangka di Kabupaten Banyuwangi menurut (Isard, 1966):

$$
\mathrm{BSR}=\frac{\Sigma \text { sektor basis }}{\Sigma \text { sektor non basis }}
$$


Kriteria Pengambilan Keputusan:

a. Jika nilai BSR > 1, maka usaha komoditas semangka pada suatu kecamatan basis mampu memenuhi kebutuhan pengembangan komoditas semangka pada kecamatan non basis di Kabupaten Banyuwangi.

b. Jika nilai BSR $\leq 1$, maka usaha komoditas semangka pada suatu kecamatan basis belum mampu memenuhi kebutuhan pengembangan komoditas semangka pada kecamatan non basis di Kabupaten Banyuwangi.

Analisis Regional Multiplier (RM) digunakan untuk mengetahui besarnya kemampuan atau dampak pengganda usaha komoditas semangka baik secara langsung maupun tidak langsung. Berikut merupakan rumus yang digunakan dalam perhitungan analisis Regional Multiplier (RM) komdoditas semangka di Kabupaten Banyuwangi menurut (Tarigan, 2016):

$$
\mathrm{RM}=\frac{\begin{array}{c}
\Sigma \text { sektor basis }+\Sigma \text { sektor non } \\
\text { basis }
\end{array}}{\sum \text { sektor basis }}
$$

Kriteria pengambilan keputusan:

a. Jika nilai RM > 1, maka usaha komoditas semangka di suatu kecamatan memiliki efek perambatan atau pengganda yang mendukung kegiatan usahatani komoditas buah di Kabupaten Banyuwangi.

b. Jika nilai $\mathrm{RM} \leq 1$, maka usaha komoditas semangka di suatu kecamatan tidak memiliki efek perambatan atau pengganda yang mendukung kegiatan usahatani komoditas buah di Kabupaten Banyuwangi.

\section{HASIL DAN PEMBAHASAN}

Wilayah Kecamatan Basis Komoditas Semangka Berdasarkan Indikator Luas Lahan dan Produksi di Kabupaten Banyuwangi

Analisis Location Quotient (LQ) merupakan salah satu teknik pendekatan dalam analisis wilayah yang dapat digunakan untuk mengetahui wilayah kecamatan basis di Kabupaten Banyuwangi yang memiliki kemampuan dan potensi dalam pengembangan komoditas semangka berdasarkan luas lahan dan produksi komoditas semangka di Kabupaten Banyuwangi. Penentuan kecamatan basis atau non basis komoditas semangka di Kabupaten Banyuwangi berdasarkan indikator produksi dan luas lahan menggunakan nilai rata-rata Location Quotient (LQ) dari data selama kurun waktu tahun 2014-2018 dilakukan guna menghindari hasil analisis yang bias dan kurang akurat. Berikut merupakan hasil analisis Location Quotient (LQ) pada Komoditas Semangka di Kabupaten Banyuwangi berdasarkan indikator luas lahan yang tersaji pada Tabel 1.

Tabel 1. Hasil Analisis Location Quotient (LQ) Komoditas Semangka di Kabupaten Banyuwangi Berdasarkan Indikator Luas Lahan, Tahun 2014-2018

\begin{tabular}{|c|c|c|c|c|c|c|}
\hline \multirow{2}{*}{ Kecamatan } & \multicolumn{5}{|c|}{ Nilai Location Quotient (LQ) } & \multirow{2}{*}{ Rata-Rata } \\
\hline & 2014 & 2015 & 2016 & 2017 & 2018 & \\
\hline Tegaldlimo & 4,094 & 1,284 & 1,357 & 0,400 & 0,931 & 1,613 \\
\hline Muncar & 6,416 & 19,522 & 12,136 & 13,247 & 13,119 & 12,888 \\
\hline Genteng & 0,748 & 3,750 & 2,876 & 3,633 & 0,000 & 2,201 \\
\hline Srono & 3,219 & 2,660 & 5,481 & 1,878 & 2,305 & 3,109 \\
\hline Singojuruh & 0,511 & 2,659 & 3,367 & 3,591 & 4,187 & 2,863 \\
\hline Banyuwangi & 0,636 & 0,588 & 2,080 & 4,757 & 0,500 & 1,712 \\
\hline
\end{tabular}

Sumber: Data Sekunder diolah (2020) 
Berdasarkan Tabel 1 dapat diketahui bahwa terjadi fluktuasi jumlah wilayah dengan nilai LQ lebih dari satu pada kurun waktu tahun 2014-2018. Pada tahun 2014 diketahui hanya terdapat tiga wilayah kecamatan yang mempunyai nilai LQ lebih dari satu dan pada tahun 2015-2017 wilayah yang memiliki nilai LQ lebih sari satu semakin meningkat jumlahnya hingga kemudian kembali menurun pada tahun 2018. Fluktuasi yang cenderung meningkat tersebut terjadi karena harga jual yang dimiliki oleh komoditas semangka yang cenderung tinggi dan mempunyai banyak peminat di pasaran, oleh karena itu banyak petani yang menggunakan lahan pertaniannya untuk menanam komoditas semangka sehingga wilayah kecamatannya bisa menghasilkan nilai LQ yang lebih dari satu. Penurunan jumlah wilayah kecamatan yang terjadi pada tahun 2018 disebabkan oleh menurunnya harga jual komoditas semangka. Penurunan harga jual terjadi karena adanya panen serentak petani semangka di seluruh wilayah kecamatan Kabupaten Banyuwangi sehingga beberapa petani enggan menanam kembali komoditas semangka. Hal tersebut berdampak pada berubahnya wilayah kecamatan yang awalnya memiliki nilai LQ lebih dari satu menjadi wilayah kecamatan dengan nilai LQ kurang dari satu sebagai akibat dari menurunnya luasan lahan komoditas semangka. Hasil ini sesuai dengan penelitian (Sihotang, 2019) yang menyebutkan bahwa fluktuasi produksi semangka dapat disebabkan oleh menurunnya luas lahan.

Berdasarkan nilai rata-rata LQnya, hasil analisis Location Quotient (LQ) selama kurun waktu tahun 2014 hingga tahun 2018 menunjukkan terdapat enam (6) wilayah kecamatan dari dua puluh empat (24) wilayah kecamatan di Kabupaten Banyuwangi yang memiliki nilai rata-rata LQ lebih besar dari satu. Artinya, enam wilayah kecamatan tersebut merupakan wilayah kecamatan yang menjadi basis komoditas semangka di Kabupaten Banyuwangi berdasarkan indikator luas lahan. Menjadi wilayah kecamatan basis komoditas semangka berarti bahwa hampir seluruh petani semangka pada enam wilayah kecamatan tersebut dalam kurun waktu tahun 2014-2018 mampu mengoptimalkan pemanfaatan lahannya, selain itu petani tersebut juga melakukan ekstensifikasi atau memperluas lahan pertanian dengan membuka lahan baru untuk menanam komoditas semangka. Wilayah kecamatan basis komoditas semangka berdasarkan indikator luas lahan tersebut adalah Kecamatan Tegaldlimo, Kecamatan Muncar, Kecamatan Genteng, Kecamatan Srono, Kecamatan Singojuruh, dan Kecamatan Banyuwangi. Wilayah kecamatan yang menjadi basis komoditas semangka berdasarkan indikator luas lahan tersebut dapat dilihat pada peta berikut ini.

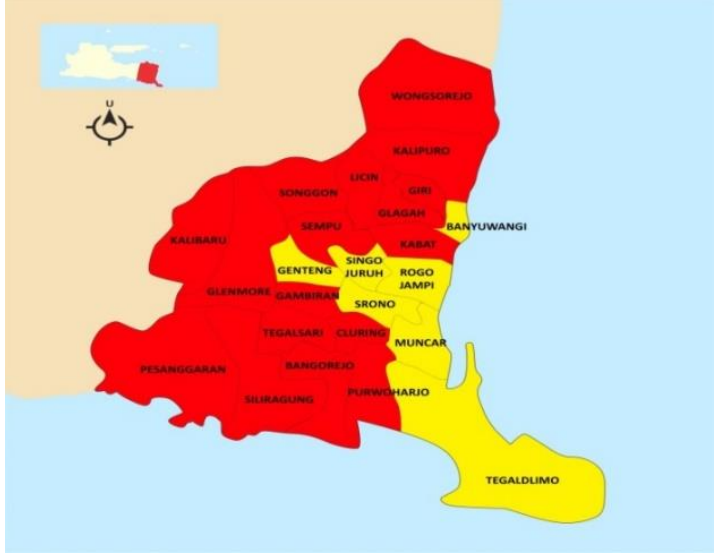

Keterangan:

Wilayah kecamatan basis komoditas semangka di Kabupaten Banyuwangi Tahun 2014-2018 Berdasarkan Luas Lahan

Wilayah kecamatan non basis komoditas semangka di Kabupaten Banyuwangi Tahun 2014-2018 Indikator Luas Lahan

Gambar 1. Pemetaan Wilayah Kecamatan Basis dan Non Basis Komoditas Semangka di Kabupaten Banyuwangi Tahun 2014-2018 Berdasarkan Indikator Luas Lahan 
Gambar 1. mengenai pemetaan wilayah kecamatan basis dan non basis komoditas semangka di atas mencerminkan bahwa wilayah kecamatan basis komoditas semangka tahun 2014-2018 berdasarkan indikator luas lahan terletak di sebelah selatan dan timur Kabupaten Banyuwangi. Secara geografis, sebagian besar wilayah kecamatan tersebut berada di dataran rendah dan sekitar garis pantai yang merupakan wilayah dimana komoditas semangka dapat tumbuh dan berkembang dengan baik. Wilayah kecamatan yang berada di dataran rendah banyak menggantungkan kegiatan perekonomiannya pada sektor pertanian. Dataran rendah yang terbentang luas dari selatan hingga utara Kabupaten Banyuwangi memiliki banyak sungai yang senantiasa mengalir sepanjang tahun sehingga dapat menguntungkan petani dalam kegiatan pertaniannya. Selain itu, faktor yang mendukung suatu wilayah menjadi wilayah kecamatan basis komoditas semangka berdasarkan indikator luas lahan yaitu adanya keengganan petani semangka untuk mengalihgunakan lahan pertanian mereka untuk menanam komoditas buah lainnya karena petani-petani tersebut sudah terbiasa dengan budidaya komoditas semangka. Kondisi tersebut sesuai dengan keadaan riil di wilayah kecamatan yang menjadi basis komoditas semangka berdasarkan indikator luas lahan dimana banyak dijumpai petani yang mananam atau mengusahakan komoditas semangka pada lahan pertaniannya.

Hasil dari analisis LQ komoditas semangka berdasarkan indikator luas lahan tersebut tidak sesuai dengan hipotesis yang diajukan. Hipotesis yang menduga bahwa wilayah kecamatan basis komoditas semangka berdasarkan indikator luas lahan di Kabupaten Banyuwangi pada tahun 2014-2018 adalah Kecamatan Srono dan Kecamatan Muncar ditolak. Ditolaknya hipotesis tersebut karena kecamatan yang menjadi basis komoditas semangka berdasarkan indikator luas lahan di Kabupaten Banyuwangi pada kurun waktu tahun 2014-2018 bukan hanya Kecamatan Srono dan Kecamatan Muncar, melainkan Kecamatan Tegaldlimo, Kecamatan Genteng, Kecamatan Singojuruh, dan Kecamatan Banyuwangi juga menjadi wilayah kecamatan basis komoditas semangka di Kabupaten Banyuwangi. Keenam wilayah kecamatan tersebut memiliki kemampuan wilayah dalam menyediakan luas lahan untuk budidaya komoditas semangka. Jika suatu wilayah kecamatan memiliki indeks LQ luas lahan lebih dari satu, maka luasan lahan di wilayah kecamatan yang bersangkutan mencukupi jika digunakan untuk menanam komoditas semangka, sedangkan kelebihan luas lahan yang dimiliki oleh wilayah tersebut bisa ditanami semangka oleh petani wilayah kecmatan lain untuk memenuhi kebutuhan semangkanya.

Analisis Location Quotient (LQ) komoditas semangka ini juga dilakukan berdasarkan indikator produksi. Tabel 2. menunjukkan jumlah wilayah kecamatan dari tiga belas wilayah kecamatan di Kabupaten Banyuwangi yang memiliki nilai LQ komoditas semangka lebih dari satu berdasarkan indikator produksi sangat fluktuatif. Wilayah kecamatan dengan nilai LQ lebih dari satu banyak mengalami perubahan selama kurun waktu lima tahun yaitu mulai tahun 2014-2018. Tahun 2014, wilayah kecamatan dengan nilai LQ lebih dari satu berjumlah enam kecamatan dan meningkat untuk tahun 2015 sejumlah sembilan kecamatan, kemudian mengalami penurunan pada tahun 2016 sejumlah lima kecamatan. Tahun 2017, wilayah kecamatan dengan nilai LQ lebih dari satu kembali meningkat dengan jumlah sembilan kecamatan dan kembali menurun pada tahun 2018 sejumlah lima kecamatan. Terjadinya fluktuasi tersebut dapat disebabkan oleh beberapa faktor diantaranya terjadinya pengurangan luasan lahan yang digunakan untuk menanam komoditas semangka, cuaca yang cenderung berubah-ubah dan tidak menentu, serta teknik budidaya yang dilakukan petani bisa menjadi penentu dari tinggi rendahnya produksi komoditas semangka di wilayah kecamatan tersebut. 
Tabel 2. Hasil Analisis Location Quotient (LQ) Komoditas Semangka di Kabupaten Banyuwangi Berdasarkan Indikator Produksi, Tahun 2014-2018

\begin{tabular}{lrrrrrr}
\hline \multirow{2}{*}{ Kecamatan } & \multicolumn{5}{c}{ Nilai Location Quotient (LQ) } & \multirow{2}{*}{ Rata-Rata } \\
\cline { 2 - 5 } & \multicolumn{1}{c}{2014} & 2015 & 2016 & 2017 & \multicolumn{1}{c}{2018} & 2,522 \\
Tegaldlimo & 3,737 & 7,589 & 0,548 & 0,678 & 0,058 & 13,264 \\
Muncar & 8,707 & 15,679 & 14,142 & 4,009 & 23,780 & 1,528 \\
Tegalsari & 0,491 & 1,435 & 0,623 & 5,092 & 0,000 & 6,535 \\
Genteng & 1,632 & 3,734 & 3,161 & 24,150 & 0,000 & 7,531 \\
Srono & 5,188 & 7,488 & 8,261 & 6,857 & 9,860 & 4,943 \\
Rogojampi & 0,874 & 1,831 & 0,239 & 16,444 & 5,327 & 1,079 \\
Kabat & 0,000 & 0,000 & 0,000 & 5,395 & 0,000 & 28,639 \\
Singojuruh & 1,630 & 13,576 & 3,093 & 15,060 & 109,835 & 1,572 \\
Wongsorejo & 0,144 & 0,036 & 0,110 & 0,000 & 7,570 &
\end{tabular}

Wilayah kecamatan yang menjadi basis komoditas semangka di Kabupaten Banyuwangi berdasarkan indikator produksi selama kurun waktu tahun 2014-2018 terdapat sembilan (9) kecamatan dari dua puluh empat (24) kecamatan di Kabupaten Banyuwangi yang memiliki nilai rata-rata Location Quotient lebih besar dari satu (LQ>1). Artinya, sembilan kecamatan tersebut merupakan wilayah kecamatan yang menjadi basis komoditas semangka berdasarkan indikator produksi di Kabupaten Banyuwangi. Kegiatan usaha komoditas semangka di Kabupaten Banyuwangi dalam kurun waktu lima tahun mampu memenuhi kebutuhan komoditas semangka pada wilayahnya sendiri dan dapat memenuhi kebutuhan komoditas semangka pada wilayah non basis komoditas semangka. Wilayah kecamatan basis komoditas semangka berdasarkan indikator produksi tersebut adalah Kecamatan Tegaldlimo, Kecamatan Muncar, Kecamatan Tegalsari, Kecamatan Genteng, Kecamatan Srono, Kecamatan Rogojampi, Kecamatan Kabat, Kecamatan Singojuruh, dan Kecamatan Wongsorejo. Berikut merupakan pemetaan wilayah kecamatan yang menjadi basis komoditas semangka berdasarkan indikator produksi.

Keterangan:

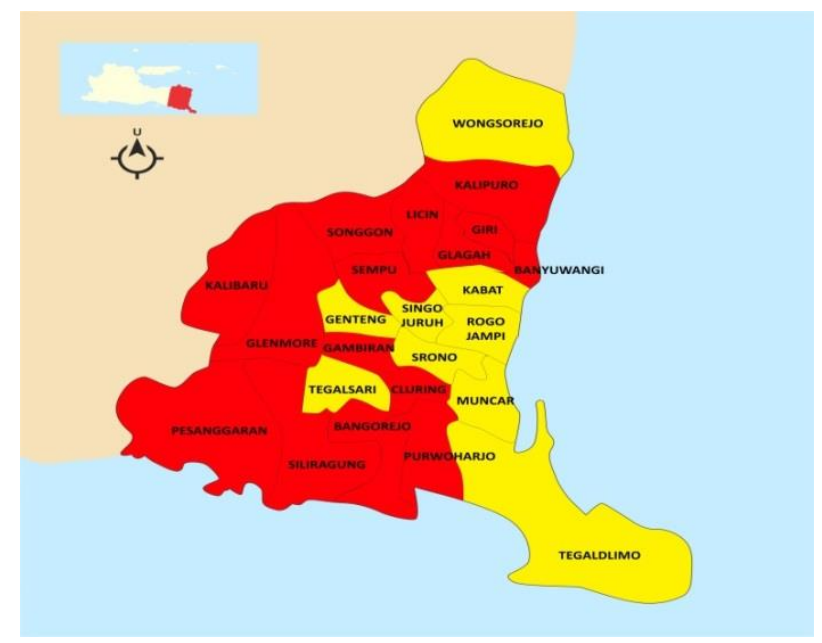

\footnotetext{
Wilayah kecamatan basis komoditas semangka di Kabupaten Banyuwangi Tahun 2014-2018 Berdasarkan Indikator Produksi

Wilayah kecamatan non basis komoditas semangka di Kabupaten Banyuwangi Tahun 2014-2018 Berdasarkan Indikator Produksi

Gambar 2. Pemetaan Wilayah Kecamatan Basis dan Non Basis Komoditas Semangka di Kabupaten Banyuwangi Tahun 2014-2018 Berdasarkan Indikator Produksi
} 
Gambar 2. mengenai pemetaan wilayah kecamatan basis komoditas semangka menunjukkan terdapat sembilan wilayah kecamatan basis komoditas semangka di Kabupaten Banyuwangi tahun 2014-2018 berdasarkan indikator produksi. Letak kesembilan kecamatan tersebut cenderung menyebar di Banyuwangi Utara, Tengah dan Selatan. Secara geografis, sebagian besar wilayah kecamatan tersebut masih berada di dataran rendah dengan curah hujan yang rendah serta menjadi daerah lintasan DAS yang mendukung tumbuh kembang komoditas semangka. Selain keadaan geografis yang mendukung, meningkatnya penguasaan teknologi, pengetahuan dan keterampilan petani dalam membudidayakan komoditas semangka menjadi salah satu alasan kesembilan kecamatan tersebut menjadi wilayah kecamatan basis komoditas semangka. Salah satu bentuk keterampilan petani yaitu dengan melihat varietas yang banyak diminati di pasar komoditas semangka, kemudian petani menggunaan bibit unggul yang sesuai dengan varietas yang diminta pasar guna menghasilkan semangka dengan kualitas terbaik. Hal tersebut menjadi penyebab tingginya produksi semangka di kesembilan kecamatan tersebut sehingga menjadi wilayah kecamatan basis.

Hasil dari analisis tersebut sesuai dengan hipotesis yang diajukan yang menduga bahwa wilayah kecamatan basis komoditas semangka berdasarkan indikator produksi di Kabupaten Banyuwangi pada tahun 2014-2018 adalah Kecamatan Srono dan Kecamatan Muncar ditolak. Alasan hipotesis tersebut ditolak karena di Kabupaten Banyuwangi yang menjadi wilayah kecamatan basis komoditas semangka berdasarkan indikator produksi tidak hanya Kecamatan Srono dan Kecamatan Muncar, tetapi terdapat beberapa wilayah kecamatan lain yang juga menjadi wilayah kecamatan basis komoditas semangka seperti Kecamatan Tegaldlimo, Kecamatan Tegalsari, Kecamatan Genteng, Kecamatan Rogojampi, Kecamatan Kabat, Kecamatan Singojuruh, dan Kecamatan Wongsorejo. Wilayah kecamatan tersebut sudah mampu memenuhi kebutuhan komoditas semangka di wilayahnya sendiri dan mampu memenuhi kebutuhan komoditas semangka pada wilayah kecamatan non basis di Kabupaten Banyuwangi. Sehingga Pemerintah Kabupaten Banyuwangi dapat merumuskan kebijakan untuk wilayah kecamatan yang menjadi basis komoditas semangka dimana peningkatan ekonomi wilayahnya bisa difokuskan melalui kegiatan komoditas semangka. Hal tersebut dilakukan melihat wilayah kecamatan tersebut memiliki potensi pengembangan komoditas semangka yang lebih baik dibandingkan dengan wilayah kecamatan lain di Kabupaten Banyuwangi.

\section{Karakteristik Penyebaran Komoditas Semangka Berdasarkan Indikator Luas Lahan dan Produksi di Kabupaten Banyuwangi}

Analisis karakteristik penyebaran komoditas semangka di Kabupaten Banyuwangi perlu dilakukan guna mengetahui wilayah kecamatan mana yang memiliki potensi untuk pengembangan komoditas semangka di Kabupaten Banyuwangi berdasarkan indikator luas lahan dan produksi komoditas semangka di Kabupaten Banyuwangi selama kurun waktu tahun 2014-2018. Analisis ini juga merupakan analisis lanjutan yang digunakan untuk memperkuat analisis Location Quotient (LQ) yang sudah dilakukan. Karakteristik penyebaran komoditas semangka di Kabupaten Banyuwangi pada kurun waktu tahun 2014 sampai 2018 dapat ditentukan dengan menggunakan dua analisis, yaitu analisis lokalisasi dan analisis spesialisasi.

1. Analisis Lokalisasi Komoditas Semangka di Kabupaten Banyuwangi

Analisis lokalisasi merupakan analisis yang digunakan untuk mengetahui apakah penyebaran komoditas semangka di Kabupaten Banyuwangi cenderung terlokalisasi pada suatu wilayah kecamatan tertentu atau menyebar di beberapa wilayah kecamatan pada 
Kabupaten Banyuwangi. Analisis lokalisasi cukup relevan untuk dilakukan guna mencari jenis komoditas yang sesuai pada wilayah kecamatan tertentu dan yang akan memberikan hasil yang optimal di suatu wilayah kecamatan tersebut. Analisis lokalisasi juga bertujuan untuk memunculkan kutub pertumbuhan yang diharapkan dapat membantu pengembangan ekonomi wilayah yang bersangkutan. Berikut merupakan hasil perhitungan koefisien lokalisasi komoditas semangka di Kabupaten Banyuwangi berdasarkan indikator luas lahan.

Tabel 3. Nilai Koefisien Lokalisasi $(\alpha)$ Positif dari Komoditas Semangka di Kabupaten Banyuwangi Berdasarkan Indikator Luas Lahan, Tahun 2014-2018

\begin{tabular}{|c|c|c|c|c|c|c|}
\hline \multirow{2}{*}{ Kecamatan } & \multicolumn{5}{|c|}{ Nilai Koefisien Lokalisasi $(\alpha)$ Positif } & \multirow{2}{*}{ Rata-Rata } \\
\hline & 2014 & 2015 & 2016 & 2017 & 2018 & \\
\hline Tegaldlimo & 0,140 & 0,032 & 0,033 & & & 0,041 \\
\hline Muncar & 0,428 & 0,550 & 0,468 & 0,588 & 0,598 & 0,527 \\
\hline Cluring & & & & 0,001 & & 0,000 \\
\hline Genteng & & 0,026 & 0,010 & 0,016 & & 0,010 \\
\hline Srono & 0,157 & 0,071 & 0,174 & 0,039 & 0,055 & 0,099 \\
\hline Rogojampi & & & & & 0,008 & 0,002 \\
\hline Kabat & & & & 0,052 & & 0,010 \\
\hline Singojuruh & & 0,012 & 0,017 & 0,022 & 0,027 & 0,016 \\
\hline Glagah & & & & & 0,013 & 0,003 \\
\hline Banyuwangi & & & 0,005 & 0,012 & & 0,003 \\
\hline Jumlah & 0,725 & 0,692 & 0,707 & 0,730 & 0,702 & 0,711 \\
\hline
\end{tabular}

Sumber: Data Sekunder diolah (2020)

Berdasarkan perhitungan analisis koefisien lokalisasi komoditas semangka di Kabupaten Banyuwangi berdasarkan indikator luas lahan yang tersaji pada Tabel 3. menunjukan bahwa tidak semua wilayah kecamatan yang ada di Kabupaten Banyuwangi memiliki nilai koefisien lokalisasi positif pada setiap tahunnya. Selain itu, tabel di atas juga menunjukkan adanya fluktuasi nilai koefisien lokalisasi komoditas semangka di Kabupaten Banyuwangi dalam kurun waktu tahun 2014-2018. Nilai koefisien lokalisasi terkecil terjadi pada tahun 2015 dengan nilai koefisien lokalisasi sebesar 0,692. Nilai koefisien lokalisasi terbesar terjadi pada tahun 2017 dengan nilai koefisien lokalisasi sebesar 0,730. Nilai koefisien lokalisasi komoditas semangka berdasarkan indikator luas lahan pada tahun 2014-2018 menunjukkan nilai koefisien yang kurang dari satu. Artinya, lahan yang digunakan untuk menanam komoditas semangka menyebar di beberapa wilayah kecamatan di Kabupaten Banyuwangi dan tidak terkonsentrasi hanya di satu wilayah kecamatan di Kabupaten Banyuwangi saja.

Tabel 3. juga menunjukkan bahwa di Kabupaten Banyuwangi dalam kurun waktu tahun 2014-2018 terdapat dua wilayah kecamatan yang memiliki nilai koefisien lokalisasi positif secara konsisten setiap tahunnya. Kedua wilayah kecamatan tersebut yaitu, Kecamatan Muncar dan Kecamatan Srono. Nilai lokalisasi yang senantiasa positif pada kurun waktu tahun 2014-2018 didapatkan karena kedua wilayah kecamatan tersebut memiliki rasio luas lahan komoditas semangka di wilayah kecamatan dan luas lahan komoditas semangka di Kabupaten Banyuwangi yang lebih besar daripada rasio antara total luas lahan komoditas hortikultura buah di wilayah kecamatan dan total luas lahan komoditas hortikultura buah di Kabupaten Banyuwangi pada sepanjang tahun 2014-2018. Koefisien lokalisasi komoditas semangka di Kabupaten Banyuwangi pada tahun 2014-2018 memiliki jumlah nilai positif kurang dari satu dengan nilai rata-rata sebesar 0,711. Artinya, dalam kurun waktu lima tahun kegiatan usahatani komoditas semangka di Kabupaten Banyuwangi adalah menyebar di beberapa wilayah kecamatan. 
Menyebarnya kegiatan usahatani komoditas semangka di Kabupaten Banyuwangi menunjukkan bahwa lahan pertanaman atau agroklimat di wilayah kecamatan Kabupaten Banyuwangi sesuai apabila digunakan untuk berusahatani komoditas semangka. Hal ini sejalan dengan pendapat (Syofia et al., 2014) yang menyatakan bahwa tanaman semangka dapat ditanam di wilayah yang memiliki iklim kering dan panas dengan suhu sekitar 25$26^{\circ} \mathrm{C}$, kondisi tanah yang cukup gembur dan sedikit berpasir, serta ketinggian tempat sekitar 0-400 m dpl. Bedasarkan informasi dari (BPS_Banyuwangi, 2018), Kabupaten Banyuwangi merupakan kabupaten yang memiliki banyak pantai yang mana daerah tersebut memiliki kondisi tanah cukup gembur dan berpasir sehingga banyak digunakan petani untuk areal pertanaman komoditas semangka. Iklim panas dan ketinggian tempat di Kabupaten Banyuwangi yang mencapai 0-2.500 m dpl juga sesuai untuk lahan pertanaman komoditas semangka.

Hasil dari analisis lokalisasi berdasarkan indikator luas lahan sesuai dengan hipotesis yang diajukan. Hal tersebut berarti hipotesis yang menduga bahwa karakteristik penyebaran komoditas semangka di Kabupaten Banyuwangi pada tahun 2014-2018 tidak terlokalisasi diterima. Diterimanya hipotesis tersebut karena kegiatan usahatani komoditas semangka menyebar di beberapa kecamatan di Kabupaten Banyuwangi. Kabupaten Banyuwangi memiliki karakteristik wilayah yang sesuai untuk budidaya komoditas semangka sehingga membuat komoditas ini tidak hanya tumbuh dan diusahakan di satu wilayah kecamatan saja namun juga pada wilayah kecamatan lainnya.

Analisis lokalisasi komoditas semangka di Kabupaten Banyuwangi juga dilakukan dengan menggunakan indikator produksi. Berikut merupakan hasil dari perhitungan menggunakan analisis lokalisasi komoditas semangka di Kabupaten Banyuwangi berdasarkan indikator produksi pada tahun 2014 sampai dengan 2018 yang tersaji pada Tabel 4.

Tabel 4. Nilai Koefisien Lokalisasi ( $\alpha$ ) Positif dari Komoditas Semangka di Kabupaten Banyuwangi Berdasarkan Indikator Produksi, Tahun 2014-2018

\begin{tabular}{|c|c|c|c|c|c|c|}
\hline \multirow{2}{*}{ Kecamatan } & \multicolumn{5}{|c|}{ Nilai Koefisien Lokalisasi $(\alpha)$ Positif } & \multirow{2}{*}{ Rata-Rata } \\
\hline & 2014 & 2015 & 2016 & 2017 & 2018 & \\
\hline Tegaldlimo & 0,213 & 0,331 & \multirow{5}{*}{0,557} & \multirow{3}{*}{0,106} & \multirow{3}{*}{0,249} & 0,109 \\
\hline Muncar & 0,366 & 0,386 & & & & 0,333 \\
\hline Cluring & 0,006 & 0,003 & & & & 0,002 \\
\hline Tegalsari & & 0,001 & & 0,083 & & 0,017 \\
\hline Glenmore & & 0,000 & & & & 0,000 \\
\hline Genteng & 0,003 & 0,003 & 0,008 & 0,085 & & 0,020 \\
\hline Srono & 0,181 & 0,154 & 0,231 & 0,320 & 0,334 & 0,244 \\
\hline Rogojampi & & 0,001 & & 0,006 & 0,013 & 0,004 \\
\hline Kabat & & & & 0,016 & & 0,003 \\
\hline Singojuruh & 0,002 & 0,002 & 0,006 & 0,006 & 0,026 & 0,008 \\
\hline Glagah & & & & 0,014 & 0,016 & 0,006 \\
\hline Banyuwangi & & 0,000 & 0,001 & & & 0,000 \\
\hline Giri & & & & 0,001 & & 0,000 \\
\hline Wongsorejo & & & & & 0,116 & 0,023 \\
\hline Jumlah & 0,772 & 0,882 & 0,802 & 0,637 & 0,754 & 0,769 \\
\hline
\end{tabular}

Tabel 4. menganai perhitungan analisis lokalisasi komoditas semangka di Kabupaten Banyuwangi berdasarkan indikator produksi menunjukkan terjadinya fluktuasi nilai koefisien lokalisasi positif di setiap tahun pada kurun waktu tahun 20142018. Nilai koefisien lokalisasi terkecil terjadi di tahun 2016 dengan jumlah sebesar 0,637, sedangkan nilai koefisien lokalisasi terbesar terjadi pada tahun 2015 dengan 
jumlah nilai lokalisasi sebesar 0,882. Nilai lokalisasi komoditas semangka berdasarkan indikator produksi pada kurun waktu lima tahun tersebut menunjukkan nilai yang kurang dari satu. Nilai koefisien lokalisasi yang kurang dari satu dapat diartikan bahwa produksi atau hasil panen komoditas semangka tidak hanya terpusat di satu wilayah kecamatan saja, akan tetapi menyebar di beberapa wilayah kecamatan di Kabupaten Banyuwangi. Kondisi kegiatan usahatani komoditas semangka yang menyebar dapat memberikan peluang pengembangan komoditas semangka serta dapat memberikan keuntungan bagi pelaku usaha apabila terjadi kegagalan panen di salah satu wilayah kecamatan, sehingga kebutuhan komoditas semangka dapat dipasok dari wilayah kecamatan lainnya.

Tabel 4. juga menunjukkan bahwa pada kurun waktu tahun 2014-2018 terdapat tiga kecamatan di Kabupaten Banyuwangi yang memiliki nilai koefisien lokalisasi positif secara konsisten setiap tahunnya, yaitu Kecamatan Muncar, Kecamatan Srono dan Kecamatan Singojuruh. Ketiga kecamatan tersebut mendapatkan nilai lokalisasi yang senantiasa positif karena memiliki nilai rasio produksi komoditas semangka di wilayah kecamatan dan produksi komoditas semangka di Kabupaten Banyuwangi yang lebih besar daripada rasio antara total produksi komoditas hortikultura buah di wilayah kecamatan dan total produksi komoditas hortikultura buah di Kabupaten Banyuwangi pada sepanjang tahun 2014-2018. Kabupaten Banyuwangi pada tahun 2014-2018 memiliki nilai rata-rata koefisien lokalisasi komoditas semangka sebesar 0,769 dimana nilai tersebut positif kurang dari satu.

Hasil dari analisis lokalisasi berdasarkan indikator produksi tersebut sesuai dengan hipotesis yang diajukan. Artinya, hipotesis yang menduga bahwa karakteristik penyebaran komoditas semangka di Kabupaten Banyuwangi berdasarkan indikator produksi pada tahun 2014-2018 tidak terlokalisasi diterima. Hipotesis tersebut diterima karena hasil produksi komoditas semangka dari kegiatan usahatani komoditas semangka menyebar di beberapa wilayah kecamatan di Kabupaten Banyuwangi. Menyebarnya kegiatan usahatani komoditas semangka di beberapa wilayah kecamatan tersebut karena wilayah kecamatan yang bersangkutan mempunyai karakteristik wilayah yang hampir sama sehingga komoditas semangka dapat tumbuh dan berkembang dengan baik di wilayah kecamatan tersebut.

\section{Analisis Spesialisasi Komoditas Semangka di Kabupaten Banyuwangi}

Analisis spesialisasi merupakan analisis kedua setelah analisis lokalisasi yang digunakan untuk mengetahui karakteristik penyebaran komoditas semangka di Kabupaten Banyuwangi pada tahun 2014-2018 berdasarkan indikator luas lahan dan produksi. Analisis spesialisasi dilakukan guna mengetahui apakah kegiatan usahatani komoditas semangka di Kabupaten Banyuwangi dispesialisasikan atau terkonsentrasi di wilayah kecamatan tertentu atau tidak. Berikut merupakan hasil analisis spesialisasi komoditas semangka di Kabupaten Banyuwangi berdasarkan indikator luas lahan.

Tabel 5 menunjukkan bahwa nilai rata-rata koefisien spesialisasi komoditas semangka berdasarkan indikator luas lahan berfluktuasi dari tahun ke tahun. Nilai ratarata koefisien spesialisasi tertinggi sebesar 0,355 terjadi pada tahun 2014. Nilai rata-rata koefisien spesialisasi terendah terjadi pada tahun 2017 dengan nilai sebesar 0,015. Fluktuasi nilai rata-rata koefisien spesialisasi yang terjadi pada komoditas semangka di Kabupaten Banyuwangi dapat dipengaruhi oleh kemampuan suatu wilayah kecamatan dalam menggunakan lahan pertanaman komoditas semangka dalam tiap tahunnya. 
Tabel 5. Nilai Koefisien Spesialisasi ( $\beta$ ) Positif Komoditas Semangka di Kabupaten Banyuwangi Berdasarkan Indikator Luas Lahan, Tahun 2014-2018

\begin{tabular}{lcccccr}
\hline \multirow{2}{*}{ Kecamatan } & \multicolumn{5}{c}{ Koefisien Spesialisasi Positif } & \multirow{2}{*}{ Rerata } \\
\cline { 2 - 5 } & 2014 & 2015 & 2016 & 2017 & 2018 & 0,104 \\
Tegaldlimo & 0,307 & 0,003 & 0,002 & & & 0,192 \\
Muncar & 0,537 & 0,188 & 0,062 & 0,051 & 0,121 & 0,000 \\
Cluring & & & & 0,000 & & 0,016 \\
Genteng & 0,220 & 0,017 & 0,025 & 0,004 & 0,013 & 0,056 \\
Srono & & & & & 0,006 & 0,006 \\
Rogojampi & & 0,017 & 0,013 & 0,011 & 0,032 & 0,009 \\
Kabat & & & & & 0,007 & 0,018 \\
Singojuruh & & & 0,006 & 0,016 & & 0,007 \\
Glagah & & & & & 0,011 \\
Banyuwangi & 0,355 & 0,051 & 0,020 & 0,015 & 0,036 & 0,064 \\
\hline Rerata/Tahun & & & & & &
\end{tabular}

Sumber: Data Sekunder diolah (2020)

Terdapat sepuluh wilayah kecamatan di Kabupaten Banyuwangi yang memiliki nilai koefisien spesialisasi positif bernilai kurang dari satu pada tahun 2014-2018. Nilai koefisien spesialisasi kurang dari satu yang diperoleh dari perhitungan spesialisasi berdasarkan indikator luas lahan ini berarti bahwa kesepuluh wilayah kecamatan yang menjadi basis komoditas semangka tidak menspesialisasikan areal lahan pertaniannya hanya pada komoditas semangka saja. Kesepuluh kecamatan tersebut antara lain Kecamatan Tegaldlimo, Kecamatan Muncar, Kecamatan Cluring, Kecamatan Genteng, Kecamatan Srono, Kecamatan Rogojampi, Kecamatan Kabat, Kecamatan Singojuruh, Kecamatan Glagah, dan Kecamatan Banyuwangi.

Berdasarkan Tabel 4.8 juga diketahui bahwa wilayah kecamatan dengan nilai ratarata koefisien spesialisasi komoditas semangka pada kurun waktu 2014-2018 tertinggi merupakan Kecamatan Muncar dengan nilai rata-rata sebesar 0,192. Nilai koefisien spesialisasi yang tinggi tersebut terjadi karena pada kurun waktu tahun 2014-2015, areal lahan pertanian wilayah Kecamatan Muncar banyak digunakan untuk menanam komoditas semangka. Nilai koefisien spesialisasi terendah berdasarkan indikator luas lahan diperoleh Kecamatan Cluring dengan nilai rata-rata sebesar 0,000. Nilai rata-rata koefisien spesialisasi yang rendah disebabkan oleh luasan lahan yang digunakan untuk menanam komoditas semangka tidak mampu mengimbangi luasan lahan tanaman hortikultura buah lainnya, sehingga berakibat pada nilai koefisien spesialisasi komoditas semangka yang relatif kecil.

Hasil dari analisis spesialisasi komoditas semangka di Kabupaten Banyuwangi pada tahun 2014-2018 berdasarkan indikator luas lahan sesuai dengan hipotesis yang diajukan. Artinya, hipotesis yang menduga bahwa karakteristik penyebaran komoditas semangka di Kabupaten Banyuwangi pada tahun 2014-2018 tidak terspesialisasi diterima. Hipotesis tersebut diterima karena di Kabupaten Banyuwangi pada tahun 2014-2018 tidak terjadi spesialisasi kegiatan usahatani pada satu jenis kegiatan usahatani komoditas semangka. Wilayah kecamatan yang tergolong dalam wilayah basis komoditas semangka, hampir sebagian besar areal lahan pertaniannya digunakan dalam kegiatan usahatani komoditas semangka. Namun tidak semua petani komoditas semangka berkonsentrasi atau menspesialisasikan pada kegiatan usahatani komoditas semangka saja, tetapi petani juga mengusahakan hortikultura buah lainnya seperti jeruk siam, pisang dan mangga. Dipilihnya komoditas buah tersebut selain untuk memenuhi kebutuhan wilayahnya, ketiga jenis komoditas tersebut memiliki pangsa pasar yang sama-sama menjanjikan dan 
tergolong dalam buah yang dapat dipanen sepanjang tahun tanpa memerlukan perlakuan khusus dalam budidaya hingga pasca panennya.

Analisis spesialisasi pada penelitian ini juga dilakukan berdasarkan indikator produksi. Berikut merupakan hasil analisis spesialisasi komoditas semangka berdasarkan indikator produksi yang tersaji pada tabel di bawah ini.

Tabel 6. Nilai Koefisien Spesialisasi ( $\beta$ ) Positif Komoditas Semangka di Kabupaten Banyuwangi Berdasarkan Indikator Produksi, Tahun 2014-2018

\begin{tabular}{|c|c|c|c|c|c|c|}
\hline \multirow{2}{*}{ Kecamatan } & \multicolumn{5}{|c|}{ Koefisien Spesialisasi Positif } & \multirow{2}{*}{ Rerata } \\
\hline & 2014 & 2015 & 2016 & 2017 & 2018 & \\
\hline Tegaldlimo & 0,206 & 0,373 & & & & 0,289 \\
\hline Muncar & 0,580 & 0,830 & 0,398 & 0,036 & 0,186 & 0,406 \\
\hline Cluring & 0,034 & 0,033 & & & & 0,033 \\
\hline Tegalsari & & 0,025 & & 0,050 & & 0,037 \\
\hline Genteng & 0,048 & 0,155 & 0,065 & 0,281 & & 0,137 \\
\hline Srono & 0,315 & 0,367 & 0,220 & 0,071 & 0,072 & 0,209 \\
\hline Rogojampi & & 0,047 & & 0,187 & 0,035 & 0,090 \\
\hline Kabat & & & & 0,053 & & 0,053 \\
\hline Singojuruh & 0,047 & 0,711 & 0,063 & 0,170 & 0,886 & 0,376 \\
\hline Glagah & & & & 0,004 & 0,005 & 0,004 \\
\hline Banyuwangi & & 0,063 & 0,011 & & & 0,037 \\
\hline Giri & & & & 0,003 & & 0,003 \\
\hline Wongsorejo & & & & & 0,054 & 0,054 \\
\hline Rerata/Tahun & 0,205 & 0,289 & 0,151 & 0,095 & 0,206 & 0,133 \\
\hline
\end{tabular}

Sumber: Data Sekunder diolah (2020)

Berdasarkan Tabel 6. dapat diketahui terdapat fluktuasi nilai rata-rata koefisien spesialisasi komoditas semangka berdasarkan indikator produksi dari tahun ke tahun di Kabupaten Banyuwangi. Nilai koefisien spesialisasi tertinggi terjadi pada tahun 2015 dengan nilai rata-rata per tahun sebesar 0,289. Sedangkan nilai koefisien spesialisasi terendah terjadi pada tahun 2017 dengan nilai rata-rata per tahun sebesar 0,095. Setiap wilayah kecamatan mempunyai kemampuan yang berbeda untuk memproduksi komoditas semangka pada setiap tahunnya. Hal tersebut dapat menjadi pengaruh terjadinya fluktuasi pada nilai rata-rata koefisien spesialisasi komoditas semangka berdasarkan indikator produksi. Hasil ini sejalan dengan penelitian (Bangun, 2020) yang menyatakan bahwa kemampuan spesialisasi wilayah akan berbeda karena setiap wilayah memiliki produk unggulan tertentu.

Dilihat dari indikator produksi, terdapat tiga belas wilayah kecamatan yang mempunyai nilai koefisien spesialisasi positif kurang dari satu pada komoditas semangka di Kabupaten Banyuwangi. Artinya, ketiga belas wilayah kecamatan yang menjadi basis komoditas semangka tersebut tidak menspesialisasikan kegiatan usahataninya hanya pada memproduksi komoditas semangka saja. Wilayah kecamatan tersebut yaitu Kecamatan Tegaldlimo, Kecamatan Muncar, Kecamatan Cluring, Kecamatan Tegalsari, Kecamatan Genteng, Kecamatan Srono, Kecamatan Rogojampi, Kecamatan Kabat, Kecamatan Singojuruh, Kecamatan Glagah, Kecamatan Banyuwangi, Kecamatan Giri, dan Kecamatan Wongsorejo.

Tabel 6. juga menginformasikan bahwa Kecamatan Muncar merupakan wilayah kecamatan yang mempunyai nilai rata-rata spesialisasi positif tertinggi pada kurun waktu tahun 2014-2018 dengan nilai rata-rata sebesar 0,406. Tingginya nilai koefisien spesialisasi komoditas semangka terjadi karena di kecamatan ini petani lebih dominan memproduksi komoditas semangka daripada komoditas hortikultura buah lainnya, namun 
tetap tidak menjadikan komoditas semangka sebagai satu-satunya komoditas hortikultura buah yang diusahakan oleh petani. Wilayah kecamatan dengan nilai rata-rata koefisien spesialisasi terendah dimiliki oleh Kecamatan Giri dengan nilai rata-rata sebesar 0,003. Rendahnya nilai rata-rata tersebut terjadi karena petani di Kecamatan Giri lebih dominan memproduksi komoditas hortikultura buah lainnya dibandingkan dengan komoditas semangka sehingga mempengaruhi nilai rata-rata koefisien spesialisasinya.

Analisis spesialisasi komoditas semangka di Kabupaten Banyuwangi berdasarkan indikator produksi pada tahun 2014-2018 sesuai dengan hipotesis yang diajukan. Dapat diartikan bahwa hipotesis yang menduga karakteristik penyebaran komoditas semangka di Kabupaten Banyuwangi pada tahun 2014-2018 tidak terspesialisasi diterima. Hipotesis tersebut diterima karena Kabupaten Banyuwangi tidak menspesialisasikan kegiatan usahataninya pada satu jenis kegiatan usahatani komoditas semangka. Akan tetapi, petani di wilayah kecamatan Kabupaten Banyuwangi juga menghasilkan buah-buahan lainnya seperti jeruk siam, mangga, rambutan, buah naga, dan sebagainya.

\section{Daya Dukung Kegiatan Usahatani Komoditas Semangka Terhadap Kegiatan Usahatani Tanaman Hortikultura Buah di Kabupaten Banyuwangi}

Komoditas semangka banyak dikembangkan oleh petani di Kabupaten Banyuwangi. Semangka yang dihasilkan oleh petani di Kabupaten Banyuwangi memiliki kualitas yang baik, oleh karena itu komoditas semangka di kabupaten ini banyak diminati oleh pasar lokal maupun luar daerah seperti Surabaya, Bali, Jakarta, Semarang hingga Kalimantan. Pemerintah Kabupaten Banyuwangi juga turut mendukung kegiatan usahatani komoditas semangka melalui upaya kerjasama dengan buyer-buyer besar untuk menyalurkan semangka yang dihasilkan oleh petani, sehingga permintaan komoditas semangka di Kabupaten Banyuwangi baik di pasar lokal maupun luar daerah cenderung meningkat. (Pangestika et al., 2015), menyatakan tingginya kegiatan ekspor suatu sektor yang dilakukan oleh suatu wilayah akan memberikan efek pengganda (multiplier effect) bagi pertumbuhan wilayah yang bersangkutan, dimana semakin besar ekspor suatu wilayah maka semakin tinggi pula dampak yang diberikan untuk mendukung laju pertumbuhan wilayahnya. Kebenaran dari pendapat tersebut dapat dibuktikan dengan menggunakan analisis Basic Service Ratio (BSR) dan Regional Multiplier (RM). Dilakukannya kedua analisis tersebut digunakan untuk mengetahui apakah sektor basis komoditas semangka mampu mendukung kegiatan usahatani tanaman hortikultura buah di Kabupaten Banyuwangi.

1. Analisis Basic Service Ratio (BSR) Kegiatan Usahatani Komoditas Semangka di Kabupaten Banyuwangi Tahun 2014-2018

Analisis Basic Service Ratio (BSR) merupakan alat analisis yang digunakan untuk mengetahui daya dukung atau efek pengganda yang ditimbulkan oleh kegiatan usahatani komoditas semangka pada suatu wilayah kecamatan terhadap wilayah kecamatan lain di Kabupaten Banyuwangi. Analisis BSR kegiatan usahatani komoditas semangka dilakukan berdasarkan dua indikator yaitu, indikator luas lahan dan produksi. Analisis dapat dihitung dengan membandingkan antara luas lahan atau produksi komoditas semangka yang dihasilkan pada wilayah basis dengan luas lahan atau produksi yang dihasilkan pada wilayah non basis yang diperoleh dari perhitungan LQ. Berikut merupakan hasil analisis BSR komoditas semangka di Kabupaten Banyuwangi berdasarkan indikator luas lahan tahun 2014-2018 yang tersaji pada Tabel 7. 
Tabel 7. Basic Service Ratio (BSR) Komoditas Semangka di Kabupaten Banyuwangi Berdasarkan Indikator Luas Lahan Tahun 2014-2018

\begin{tabular}{crrr}
\hline Tahun & Basis & Non Basis & BSR \\
\hline 2014 & 13,729 & 3,807 & 3,607 \\
2015 & 29,876 & 3,300 & 9,053 \\
2016 & 27,298 & 3,167 & 8,619 \\
2017 & 31,268 & 2,797 & 11,177 \\
2018 & 22,907 & 2,871 & 7,978 \\
\hline
\end{tabular}

Sumber: Data Sekunder diolah (2020)

Berdasarkan Tabel 7. dapat dilihat bahwa nilai BSR komoditas semangka di Kabupaten Banyuwangi pada tahun 2014-2018 berfluktuasi. Fluktuasi nilai BSR pada indikator luas lahan dipengaruhi oleh minat petani dalam menanam komoditas semangka itu sendiri. Nilai BSR yang lebih dari satu dapat dipertahankan dengan menjaga keberlanjutan dan meningkatkan luasan lahan yang digunakan untuk menanam komoditas semangka. Nilai BSR komoditas semangka tertinggi terjadi pada tahun 2017 dengan nilai sebesar 11,177 dimana nilai tersebut lebih dari satu. Artinya, satu bagian digunakan untuk memenuhi kebutuhan pengembangan di wilayah basisnya sendiri, sedangkan 10,177 bagian dipergunakan untuk memenuhi kebutuhan pengembangan wilayah non basis. Nilai BSR komoditas semangka terendah terjadi pada tahun 2014 dengan nilai sebesar 3,607 dimana nilai tersebut kurang dari satu yang berarti bahwa satu bagian dipergunakan untuk memenuhi kebutuhan pengembangan wilayah basis dan 2,607 bagian sisanya digunakan untuk memenuhi kebutuhan wilayah pengembangan non basis. Komoditas semangka di Kabupaten Banyuwangi pada kurun waktu tahun 2014-2018 memiliki nilai BSR yang lebih dari satu. Hal tersebut menggambarkan bahwa keberadaan kegiatan usahatani komoditas semangka di Kabupaten Banyuwangi mampu mendukung kegiatan usahatani tanaman hortikultura buah di Kabupaten Banyuwangi.

Analisis BSR komoditas semangka di Kabupaten Banyuwangi ini juga dilakukan berdasarkan indikator produksi. Berikut merupakan hasil analisis BSR komoditas semangka di Kabupaten Banyuwangi tahun 2014-2018 berdasarkan indikator produksi yang tersaji pada Tabel 8 .

Tabel 8. Basic Service Ratio (BSR) Komoditas Semangka di Kabupaten Banyuwangi Berdasarkan Indikator Produksi Tahun 2014-2018

\begin{tabular}{crrr}
\hline Tahun & Basis & Non Basis & BSR \\
\hline 2014 & 22,344 & 2,686 & 8,319 \\
2015 & 55,030 & 1,272 & 43,264 \\
2016 & 30,026 & 2,332 & 12,874 \\
2017 & 79,568 & 2,140 & 37,176 \\
2018 & 157,993 & 3,725 & 8,319 \\
\hline
\end{tabular}

Tabel 8. memperlihatkan bahwa komoditas semangka di Kabupaten Banyuwangi pada tahun 2014-2018 berdasarkan indikator produksi mempunyai nilai BSR yang fluktuatif. Tahun 2015, komoditas semangka memperoleh nilai BSR tertinggi yaitu sebesar 43,264 dimana nilai tersebut lebih dari satu. Artinya, satu bagian produksi komoditas semangka digunakan untuk memenuhi kebutuhan pengembangan di wilayah basis, sedangkan 42,264 bagian dipergunakan untuk memenuhi kebutuhan pengembangan wilayah non basis. Pada tahun 2014 dan 2018, komoditas semangka mencapai nilai BSR terendah yaitu sebesar 8,319 dimana nilai tersebut kurang dari satu. Artinya, satu bagian dipergunakan untuk memenuhi kebutuhan pengembangan wilayah 
basis dan 7,319 bagian dipergunakan untuk memenuhi kebutuhan pengembangan pada wilayah non basis. Terjadinya fluktuasi nilai BSR komoditas semangka berdasarkan indikator produksi dipengaruhi oleh tinggi atau rendahnya permintaan komoditas semangka, baik dari wilayah basis maupun wilayah non basis. Agar BSR selalu mempunyai nilai lebih dari satu, maka petani harus menjaga menjaga keberlanjutan dan peningkatan produksi komoditas semangka di wilayah kecamatan Kabupaten Banyuwangi. Hasil analisis BSR pada komoditas semangka di Kabupaten Banyuwangi tahun 2014-2018 berdasarkan indikator produksi memiliki nilai BSR yang lebih dari satu. Hal tersebut menunjukkan bahwa adanya kegiatan usaha komoditas semangka mampu mendukung kegiatan usaha tanaman hortikultura buah di Kabupaten Banyuwangi.

Analisis BSR komoditas semangka menghasilkan nilai lebih dari satu dimana hasil tersebut sesuai dengan hipotesis yang diajukan. Oleh karena itu, hipotesis yang menduga bahwa komoditas semangka mampu mendukung kegiatan usahatani tanaman hortikultura buah di Kabupaten Banyuwangi diterima. Semakin besar nilai BSR yang diperoleh akan menunjukkan semakin besar luasan lahan yang digunakan untuk menanam komoditas semangka serta semakin besar produksi semangka yang dihasilkan petani untuk mendukung kegiatan usahatani tanaman hortikultura buah khususnya komoditas semangka di Kabupaten banyuwangi.

2. Analisis Regional Multiplier (RM) Kegiatan Usahatani Komoditas Semangka di Kabupaten Banyuwangi Tahun 2014-2018

Analisis Regional Multiplier (RM) merupakan analisis lanjutan dari analisis Basic Service Ratio (BSR) yang digunakan untuk mengetahui daya dukung komoditas semangka terhadap kegiatan usaha tanaman hortikultura buah di Kabupaten Banyuwangi. Hasil analisis RM menunjukkan besaran angka pengganda atau efek perambatan yang ditimbulkan dari kegiatan usaha komoditas semangka pada suatu wilayah terhadap kegiatan usaha komoditas semangka di wilayah basis. Analisis RM selain dilakukan untuk menggambarkan suatu hubungan secara langsung maupun tidak langsung dari keberadan sektor basis komoditas semangka juga dilakukan untuk mengetahui pengaruh yang ditimbulkan oleh komoditas semangka sebagai komoditas yang memiliki efek pengganda terhadap kegiatan usaha tanaman hortikultura buah di Kabupaten Banyuwangi.

Analisis Regional Multiplier (RM) komoditas semangka di Kabupaten Banyuwangi dilakukan berdasarkan indikator luas lahan dan produksi, dimana hasil dari analisis RM dapat diketahui dengan menghitung perbandingan antara luas lahan atau produksi komoditas semangka di Kabupaten Banyuwangi pada tahun 2014-2018 dengan luas lahan atau produksi komoditas semangka pada wilayah kecamatan yang menjadi basis komoditas semangka di Kabupaten Banyuwangi pada tahun 2014-2018. Besaran nilai RM komoditas semangka di Kabupaten Banyuwangi pada tahun 2014-2018 berdasarkan indikator luas lahan disajikan dalam Tabel 9. berikut.

Tabel 9. Nilai Regional Multiplier (RM) Komoditas Semangka di Kabupaten Banyuwangi Berdasarkan Indikator Luas Lahan Tahun 2014-2018

\begin{tabular}{crrr}
\hline Tahun & \multicolumn{1}{c}{ Basis } & Non Basis & Regional Multiplier (RM) \\
\hline 2014 & 13,729 & 3,807 & 1,277 \\
2015 & 29,876 & 3,300 & 1,110 \\
2016 & 27,298 & 3,167 & 1,116 \\
2017 & 31,268 & 2,797 & 1,089 \\
2018 & 22,907 & 2,871 & 1,125 \\
\hline
\end{tabular}

Sumber: Data Sekunder diolah (2020) 
Berdasarkan hasil di atas, dapat diketahui bahwa berdasarkan indikator luas lahan nilai RM tertinggi terjadi pada tahun 2014 yaitu sebesar 1,277, sedangkan nilai RM terendah terjadi pada tahun 2017 yaitu sebesar 1,089. Nilai RM komoditas semangka pada kurun waktu tahun 2014-2018 cenderung stabil, yaitu berada pada sekitar 1,089 sampai 1,277. Artinya, kegiatan usahatani komoditas semangka di Kabupaten Banyuwangi memiliki potensi yang besar untuk dikembangkan. Hasil penelitian ini searah dengan penelitian (Bangun, 2020)yang menyebutkan bahwa nilai RM (Regional Multiplier) menjadi indicator untuk melihat potensi suatu komoditas di suatu wilayah.

Pada tahun 2014-2018 kegiatan usahatani komoditas semangka di Kabupaten Banyuwangi berdasarkan indikator luas lahan memiliki nilai RM yang lebih dari satu $(\mathrm{RM}>1)$. Artinya, keberadaan kegiatan usahatani komoditas semangka di wilayah kecamatan Kabupaten Banyuwangi dapat memberikan efek pengganda terhadap kegiatan usahatani komoditas semangka di wilayah kecamatan basis. Sehingga, wilayah kecamatan yang menjadi basis komoditas semangka dapat mendukung pengembangan kegiatan usahatani tanaman hortikultura buah, khususnya komoditas semangka di Kabupaten Banyuwangi. Efek pengganda yang ditimbulkan dari adanya wilayah kecamatan basis komoditas semangka berdasarkan indikator luas lahan berupa tersediannya lahan yang digunakan untuk menanam komoditas semangka oleh petani dari wilayah kecamatan lain yang bukan basis komoditas semangka untuk memenuhi kebutuhan komoditas semangka di wilayahnya.

Analisis RM komoditas semangka di Kabupaten Banyuwangi juga dilakukan dengan menggunakan indikator produksi. Berikut merupakan hasil dari perhitungan analisis RM komoditas semangka berdasarkan indikator produksi yang tersaji pada tabel di bawah ini.

Tabel 10. Nilai Regional Multiplier (RM) Komoditas Semangka di Kabupaten Banyuwangi Berdasarkan Indikator Produksi Tahun 2014-2018

\begin{tabular}{crrr}
\hline Tahun & \multicolumn{1}{c}{ Basis } & Non Basis & Regional Multiplier (RM) \\
\hline 2014 & 22,344 & 2,686 & 1,120 \\
2015 & 55,030 & 1,272 & 1,023 \\
2016 & 30,026 & 2,332 & 1,078 \\
2017 & 79,568 & 2,140 & 1,027 \\
2018 & 157,993 & 3,725 & 1,024 \\
\hline
\end{tabular}

Sumber: Data Sekunder diolah (2020)

Berdasarkan Tabel 10. dapat diketahui bahwa kegiatan usaha komoditas semangka berdasarkan indikator produksi pada tahun 2014 memiliki nilai RM tertinggi yaitu sebesar 1,120, sedangkan pada tahun 2015 memiliki nilai RM terendah yaitu sebesar 1,023. Pada tahun 2014-2018 nilai RM komoditas semangka cenderung stabil, yaitu berada pada sekitar 1,023 sampai 1,120 dalam kata lain Kabupaten Banyuwangi mempunyai potensi yang besar dalam pengembangan kegiatan usahatani komoditas semangka.

Berdasarkan indikator produksi, kegiatan usahatani komoditas semangka di Kabupaten Banyuwangi pada tahun 2014-2018 mempunyai nilai RM yang lebih dari satu $(\mathrm{RM}>1)$. Hal tersebut berarti bahwa kegiatan usahatani komoditas semangka yang berada di wilayah kecamatan Kabupaten Banyuwangi dapat memberikan efek pengganda terhadap kegiatan usahatani komoditas semangka di wilayah kecamatan basis. Hal tersebut menandakan bahwa wilayah kecamatan basis komoditas semangka di Kabupaten Banyuwangi dapat mendukung pengembangan kegiatan usahatani tanaman hortikultura 
buah, khususnya komoditas semangka. Efek pengganda yang timbul dari adanya wilayah kecamatan basis komoditas semangka berdasarkan indikator produksi yaitu setelah kebutuhan komoditas semangka dari wilayah kecamatan basis tercukupi, kelebihan produksi komoditas semangkanya dapat digunakan untuk memenuhi kebutuhan komoditas semangka pada wilayah non basis komoditas semangka di Kabupaten Banyuwangi.

Hasil dari analisis RM komoditas semangka di Kabupaten Banyuwangi pada tahun 2014-2018 sesuai dengan hipotesis yang diajukan. Artinya, hipotesis yang menduga bahwa wilayah basis komoditas semangka mampu mendukung kegiatan usahatani tanaman hortikultura buah di Kabupaten Banyuwangi diterima. Hipotesis tersebut diterima karena hasil analisis RM komoditas semangka Kabupaten Banyuwangi pada tahun 2014-2018 menghasilkan nilai yang lebih dari satu. Kegiatan usahatani komoditas semangka yang berada di wilayah kecamatan Kabupaten Banyuwangi dapat memberikan efek pengganda terhadap kegiatan usahatani komoditas semangka di wilayah kecamatan basis. Kegiatan usahatani komoditas semangka di wilayah kecamatan basis dapat memberikan efek pengganda terhadap peningkatan pendapatan petani semangka, peningkatan tenaga kerja, penyedia sarana dan prasarana produksi, serta jasa dan pengangkutan komoditas semangka. Efek pengganda tersebut juga mempengaruhi peningkatan perekonomian Kabupaten Banyuwangi sebagai akibat dari peningkatan kegiatan usahatani komoditas semangka di Kabupaten Banyuwangi.

\section{KESIMPULAN}

Berdasarkan hasil-hasil analisis yang telah dilakukan, maka kesimpulan yang dapat diambil yaitu wilayah kecamatan yang menjadi basis komoditas semangka di Kabupaten Banyuwangi berdasarkan indikator luas lahan yaitu Kecamatan Tegaldlimo, Kecamatan Muncar, Kecamatan Genteng, Kecamatan Srono, Kecamatan Singojuruh, dan Kecamatan Banyuwangi. Untuk indikator produksi yaitu Kecamatan Tegaldlimo, Kecamatan Muncar, Kecamatan Tegalsari, Kecamatan Genteng, Kecamatan Srono, Kecamatan Rogojampi, Kecamatan Kabat, Kecamatan Singojuruh, dan Kecamatan Wongsorejo. Karakteristik penyebaran komoditas semangka di Kabupaten Banyuwangi tidak terlokalisasi. Kegiatan usahatani komoditas semangka tidak terpusat pada satu wilayah kecamatan saja melainkan menyebar ke beberapa wilayah kecamatan di Kabupaten Banyuwangi. Kabupaten Banyuwangi juga tidak menspesialisasikan kegiatan usahataninya hanya pada kegiatan usahatani komoditas semangka saja namun juga pada kegiatan usahatani hortikultura buah lainnya seperti jeruk, pisang dan mangga. Hasil analisis Basic Service Ratio (BSR) dan Regional Multiplier (RM) komoditas semangka menghasilkan nilai lebih dari satu. Keberadaan kegiatan usahatani komoditas semangka mampu mendukung kegiatan usahatani tanaman hortikultura buah di Kabupaten Banyuwangi. Pengembangan komoditas semangka perlu didukung oleh Pemerintah melalui penciptaan agroindustri semangka dan dukungan investasi guna mengembangkan komoditas semangka di Banyuwangi.

\section{DAFTAR PUSTAKA}

Bangun, R. H. B. (2020). Analisis Perwilayahan Komoditas dan Kontribusi Kopi Arabika Terhadap Pembangunan Wilayah Kabupaten Tapanuli Utara Commodity Area Analysis and Contribution of Arabica Coffee to Regional Development in North Tapanuli Regency. Jurnal Agriuma, 2(April), 1-10. 
BPS_Banyuwangi. (2018). Kabupaten Banyuwangi dalam Angka 2018. BPS Banyuwangi.

Daniel, A. (2016). Insentif Bertanam Semangka Tanpa Biji: Manisnya Laba Semanis Buahnya. Pustaka Baru Press.

Dirjen_Hortikultura. (2017). Laporan Kinerja Direktorat Jenderal Hortikultura Tahun 2017. Direktoral Jenderal Hortikultura.

Disperta_Banyuwangi. (2018). Pertanian, Perkebunan dan Peternakan. htpps://www.banyuwangikab.go.id/profil/pertanian.html.

Firdaus, M., Paramu, H., Suherman, \& Jusuf, C. (2009). Penentuan Komoditas Pertanian Unggulan di Kabupaten Jember. JSEP : Jurnal Sosial Ekonomi Pertanian, 3(1), 3339.

Hendayana, R. (2003). Aplikasi Metode Location Quotient (LQ) dalam Penentuan Komoditas Unggulan Nasional. Jurnal Informatika Pertanian, 12(Desember 2003), 1-21. http://www.litbang.pertanian.go.id/warta-ip/pdf-file/rahmadi-12.pdf

Isard, W. (1966). Methods of Regional Analysis: an Introduction to Regional Science. The M.I.T. Press.

Kartikaningdyah, E. (2012). Analisis Location Quotient dalam Penentuan Produk Unggulan pada Beberapa Sektor di Kabupaten Lingga Kepulauan Riau. Jurnal Integrasi, 4(1), 31-46. https://jurnal.polibatam.ac.id/index.php/JI/article/view/235

Kementerian_Pertanian. (2017). Statistik Pertanian 2017. Pusat Data dan Sistem Informasi Pertanian Kementerian Pertanian Republik Indonesia.

Keratorop, M., Widiatmaka, W., \& Suwardi, S. (2016). Arahan Pengembangan Komoditas Tanaman Pangan di Kabupaten Boven Digoel Provinsi Papua. Journal of Natural Resources and Environmental Management, 6(2), 141-150. https://doi.org/10.19081/jpsl.2016.6.2.141

Mulyono, J., \& Munibah, K. (2016). Pendekatan Location Quotient Dan Shift Share Analysis Dalam Penentuan Komoditas Unggulan Tanaman Pangan Di Kabupaten $\begin{array}{llll}\text { Bantul. Informatika Pertanian, } 221 . & 25(2),\end{array}$ https://doi.org/10.21082/ip.v25n2.2016.p221-230

Pangestika, V. B., Syafrial, \& Suhartini. (2015). Terhadap Kinerja Ekonomi Jagung Di Indonesia the Simulation of Corn Import Tarif Policy Toward the Productivity of Corn Economy in Indonesia. Habitat, 26(2), 100-107.

Qomariyah, S., Mustapit, \& Supriono, A. (2018). Analisis Potensi Wilayah Berbasis Komoditas Pertanian Tanaman Pangan serta Kontribusinya terhadap Perekonomia Kabupaten Bondowoso. JSEP : Jurnal Sosial Ekonomi Pertanian, 11(1), 66-72.

Sihotang, J. P. (2019). Analisis Perwilayahan Komoditas Semangka (Citrullus Lanatus) Di Kabupaten Deli Serdang Provinsi Sumatera Utara. Universitas Sumatera Utara.

Supriyanto, A., Basukianto, B., \& Rozaq, J. A. (2017). Classification of SME and Potential Areas Based on Map as Economic Development Strategy (Klasterisasi UMKM dan Potensi Wilayah Berbasis Peta Sebagai Strategi Pengembangan $\begin{array}{lllll}\text { Ekonomi Daerah). Journal } & \text { Pekommas, } & \text { 2(2), } & \end{array}$ https://doi.org/10.30818/jpkm.2017.2020204 
Syofia, I., Khair, H., \& Anwar, K. (2014). Respon Pertumbuhan dan produksi Tanaman Kacang Hijau (Vigna radiata L.) terhadap Pemberian Pupuk Organik Padat dan Pupuk Organik Cair. Agrium, 19(1), 68-76.

Tarigan, R. (2016). Perencanaan Pembangunan Wilayah. PT Bumi Aksara.

Tumangkeng, S. (2018). Analisis Potensi Ekonomi di Sektor dan Sub Sektor Pertanian, Kehutanan dan Perikanan Kota Tomohon. Jurnal Berkala Ilmiah Efisiensi, 18(01), 127-138.

Warpani, S. (1980). Analisis Kota dan Daerah. Penerbit ITB. 